\title{
Correlation of gender and age with serum adipokines level in north indian adults
}

\author{
Pravesh Kumar ${ }^{1}$, Neena Srivastava ${ }^{2}$, Sunita Tiwari ${ }^{3}$, Narsingh Verma ${ }^{1}$, Shivani Pandey ${ }^{4}$, \\ Naveen Bhartia Porwal' ${ }^{1}$, Pradeep Kumar ${ }^{2}$, Rahul ${ }^{1}$
}

${ }^{1}$ Resident, Department of Physiology, King George's Medical University, Lucknow, India, ${ }^{2}$ Professor, Department of Physiology, King George's Medical University, Lucknow, India, ${ }^{3}$ Professor and Head, Department of Physiology, King George's Medical University, Lucknow, India, ${ }^{4}$ Assistant Professor, Department of Biochemistry, King George’s Medical University, Lucknow, India, 226003

\section{A B S TRA C T}

Objective: There are two forms of adipose tissue, brown adipose tissue (BAT) and white adipose tissue (WAT). Distribution of adipose tissue differs in different gender and different age group. Adipose tissue expresses various secretary proteins, including leptin and adiponectin, collectively called adipokines. The purpose of this study to elucidated the correlation of serum leptin, serum adiponectin levels with age and gender in north Indian population. Materials and Methods: 100 subjects (55 male, 45 female) aged between 18-25 yrs were included in the study. Blood sample were taken after overnight fasting for biochemical assay. Serums were separated by centrifugation method. Serum leptin and serum adiponectin were analyzed by using RayBio ELISA Kit. Result: The serum leptin (pg) was significantly $(p=0.001)$ higher among female $(428.28 \pm 83.06)$ subjects compared with males (365.42 \pm 102.56$)$. Similarly, serum adiponectin $(p g)$ level was also significantly $(p=0.02)$ higher among females $(5313.15 \pm 1151.12)$ than males (4794.72 \pm 1078.38$)$. The age was mildly and negatively correlated with Serum adiponectin $(r=-0.317, p=0.001)$ and had no correlation with serum leptin levels. Conclusion: Serum adipokines levels in young north Indian adults are influenced by gender and age of subjects, suggests that female subject, relative to the males, are at increased risk for obesity-related metabolic co-morbidities.
Access this article online Website:

http://nepjol.info/index.php/AJMS

DOI: 10.3126/ajms.v6i5.11862

Key words: Serum leptin, Serum adiponectin, Gender

\section{INTRODUCTION}

Obesity is a complex, multifactorial disorder characterized by an excess of adipose tissue or body fat. In obesity there is excessive adipose tissue mass. ${ }^{1}$ Obesity arises when energy intake exceeds energy expenditure. There is convincing experimental evidence showing that the balance between energy intake (food consumption) and energy expenditure is tightly regulated. A homeostatic network maintain energy store through a complex interplay between the feeding regulatory centers in the central nervous system (CNS), particularly in the hypothalamus and the peripheral fat stores. $^{2}$

Adipose tissue is one of the largest tissues in human body and total amount deposited will have a detrimental impact on regular body function. The quantity of body fat could be significant source of hundreds of biologically active molecules the adipokines including more than 50 cytokines, chemokines, hormone like growth factor and other mediators like leptin, adiponectin, visfatin, apelin, vaspin, hepcidine, chemerin, omentin including tumor necrosis factor alfha (TNF $\alpha$ ), monocyte chemoattractant protein-1 (MCP-1) and plasminogen activator protein (PAI).

Leptin is a $16 \mathrm{kDa}$ protein hormone that plays a key role in regulating energy intake and energy expenditure, including appetite and metabolism. Leptin acts primarily on the hypothalamus. leptin activates POMC neurons, activated POMC neuron release $\alpha-\mathrm{MSH}$ into the synapses, which activates the projected neurons via binding to MCRs and lead to anorexigenic responses and increased energy expenditure.

Address for Correspondence:

Dr. Neena Srivastava, Professor, Department of Physiology, King George's Medical University, Lucknow, India, 226003.

Mobile: 09415024024

E-mail: drneenasrivastava@hotmail.com.

(C) Copyright AJMS 
Simultaneously, leptin inhibits NPY/AgRP neurons, offsetting the antagonistic effect of AgRP on MCRs. ${ }^{3}$ NPY/AgRP neurons stimulates orexigenic responses and inhibits POMC neuron via direct synaptic connection. ${ }^{4}$

Adiponectin has insulin-sensitizing actions in the liver, and lowers blood glucose levels in diabetic animals by improving insulin-mediated suppression of gluconeogenesis. In liver and skeletal muscle, adiponectin also improves glucose utilization and stimulates fatty acid oxidation via a pathway that involves AMP kinase (AMPK) and acetylCoA carboxylase. In the present study, we elucidated the correlation of serum leptin, serum adiponectin levels with age and gender in north Indian population.

\section{MATERIALS AND METHODS}

This was a cross sectional study enrolled with hundred subjects (55 male, 45 female) aged (Table 1) between 18 to 25 years (Table 2). This study was approved by ethical committee of institute.

\section{Inclusion criteria}

Age between 18 to 25 years irrespective of sex, apparently healthy subjects, Place of birth north India.

\section{Exclusion criteria}

Any chronic illness eg.- Tuberculosis, COPD; Any apparent cardiac illness, Any apparent metabolic disorder eg.Diabetes Mellitus, Hypertension, Any congenital disorder.

\section{Biochemical analysis}

Blood samples were taken after overnight fasting and serum was separated, after coagulation, by centrifugation method. Serum leptin and serum adiponectin were estimated by using RayBio ELISA Kit.

\section{Statistical analysis}

The results were presented in mean \pm SD and percentages. The $\mathrm{p}$-value $<0.05$ was considered significant. All the analysis was carried out by using SPSS 16.0 version (Chicago, Inc., USA).

\section{RESULTS}

The serum leptin (pg) levels (Table 3) were significantly $(p=0.001)$ higher among female (428.28 \pm 83.06$)$ subjects compared with males (365.42 \pm 102.56$)$. Similarly, serum adiponectin (pg) levels (Table 4) were also significantly $(\mathrm{p}=0.02)$ higher among females $(5313.15 \pm 1151.12)$ than males (4794.72 \pm 1078.38$)$. The age was mildly and negatively correlated with Serum adiponectin $(\mathrm{r}=-0.317, \mathrm{p}=0.001)$ and had no correlation with serum leptin levels (Table 4).

\begin{tabular}{lcc}
\multicolumn{3}{l}{ Table 1: Gender distribution of the subjects } \\
\hline Gender & No. $(\mathbf{n = 1 0 0 )}$ & Percentage \\
\hline Male & 55 & 55.0 \\
Female & 45 & 45.0 \\
\hline
\end{tabular}

\begin{tabular}{lcc}
\multicolumn{3}{l}{ Table 2: Age distribution of the subjects } \\
\hline \multicolumn{4}{l}{ Age in years } & No. $(\mathbf{n = 1 0 0})$ & Percentage \\
\hline$<20$ & 17 & 17.0 \\
$20-22$ & 62 & 62.0 \\
$>22$ & 21 & 21.0 \\
Mean \pm SD (Min.-Max.) & $21.35 \pm 1.50(18-24)$ & \\
\hline Min.: Minimum, Max.: Maximum &
\end{tabular}

\begin{tabular}{|c|c|c|c|}
\hline \multirow{2}{*}{$\begin{array}{l}\text { Biochemical } \\
\text { parameters }\end{array}$} & \multicolumn{2}{|c|}{ Mean士SD } & \multirow[t]{2}{*}{ p-value } \\
\hline & Male $(n=55)$ & Female $(n=45)$ & \\
\hline Serum leptin (pg) & $365.42 \pm 102.56$ & $428.28 \pm 83.06$ & $0.001^{*}$ \\
\hline $\begin{array}{l}\text { Serum adiponectin } \\
\text { (pg) }\end{array}$ & $4794.72 \pm 1078.38$ & $5313.15 \pm 1151.12$ & $0.02^{*}$ \\
\hline
\end{tabular}

\begin{tabular}{|c|c|}
\hline Biochemical parameters & Age \\
\hline Serum leptin (pg) & $\begin{array}{l}r=0.092 \\
P=0.363\end{array}$ \\
\hline Serum adiponectin (pg) & $\begin{array}{c}r=-0.317^{* *} \\
P=0.001\end{array}$ \\
\hline
\end{tabular}

*Correlation is significant at the 0.05 level (2-tailed). ${ }^{*}$ Correlation is significant at the 0.01 level (2-tailed)

\section{DISCUSSION}

Data was analyzed according to gender, and we observed that serum leptin levels were significantly higher in females (428.28 183.06$)$ subjects as compared with male (365.42 \pm 102.56$)$ subjects. There are several possible explanation for difference. One is that females have more adipose tissue than males, but some literature indicate that estrogen level are higher in female which stimulate adipose tissue and increase the production of leptin, whereas higher androgen level in male suppress the level of leptin production. ${ }^{5}$ Finding of Daghari et $\mathrm{al}^{6}$ in 2007 corroborate with our results.

In the present study, we also studied the correlation of serum adiponectin levels with different genders and observed that serum adiponectin levels are significantly $(\mathrm{p}=0.02)$ higher in females $(5313.15 \pm 1151.12)$ as compared with males (4794.72 \pm 1078.38$)$. Same results also obtained by Böttner A. et al, 2004 and Chamukuttan Snehalatha et al, ${ }^{8} 2008$. 
In the present study age does not show any correlation with serum leptin levels. Zhong $\mathrm{N}$ et al, ${ }^{9} 2005$ found high serum leptin levels in postmenopausal women than premenopausal women, but after adjusting for BMI no association of serum leptin with age was found. Our study also showed significant negative correlation with age and serum adiponectin levels. This finding was contradicted by Obata Y. et al, ${ }^{10} 2013$ as they observed that serum adiponectin levels are significantly and positively associated with age in healthy subjects, but finding of our study was supported by Sunita J Ramanand et al, ${ }^{11} 2014$ as they found that adiponectin levels decreases as age advances.

\section{CONCLUSION}

Serum adipokines levels in young north Indian adults are influenced by gender and age of subjects, suggests that female subject, relative to the males, are at increased risk for obesity-related metabolic co-morbidities. Owing to small sample size of this study we were not definitely established our results. Hence, further studies required in future with large sample size.

\section{REFERENCES}

1. Apovian CM, Bigornia S, Mott M, Meyers MR, Ulloor J, Gagua M, et al. Adipose Macrophage Infiltration is Associated With Insulin Resistance and Vascular Endothelial Dysfunction in Obese Subjects. Arteriosclerosis, Thrombosis, and Vascular Biology 2008; 28:1654-1659.

2. Georgescu D, Sears RM, Hommel JD, Barrot M, Bolaños CA, Marsh DJ, et al. The Hypothalamic Neuropeptide Melanin-
Concentrating Hormone Acts in the Nucleus Accumbens to Modulate Feeding Behavior and Forced-Swim Performance. The Journal of Neuroscience 2005; 25(11): 2933-2940.

3. Luquet S, Perez FA, Hnasko TS and Palmiter RD. NPY/AgRP Neurons are Essential for Feeding in Adult Mice but Can Be Ablated in Neonates. Science 2005; 310 (5748): 683-685.

4. Morton GJ, Cummings DE, Baskin DG, Barsh GS and Schwartz MW. Central nervous system control of food intake and body weight. Nature 2006; 443:S 289-295.

5. Kapoor D, Clarke S, Stanworth R, Channer KS and Jones TH. The effect of testosterone replacement therapy on adipocytokines and $\mathrm{C}$-reactive protein in hypogonadal men with type 2 diabetes. Eur J Endocrinol 2007; 595-602.

6. Al-Daghri NM, Al-Attas OS, Al-Rubeaan $\mathrm{K}$ and Mohieldin M. Serum leptin and its relation to anthropometric measures of obesity in pre-diabetic Saudis. Cardiovascular Diabetology 2007; 6-18.

7. Böttner A, Kratzsch J, Müller G, Kapellen TM, Blüher S, Keller E, et al. Gender differences of adiponectin levels develop during the progression of puberty and are related to serum androgen levels. J Clin Endocrinol Metab 2004; 89(8):4053-4061.

8. Snehalatha C, Yamuna A and Ramachandran A. Plasma Adiponectin Does Not Correlate With Insulin Resistance and Cardiometabolic Variables in Nondiabetic Asian Indian Teenagers. Diabetes Care 2008; 31(12): 2374-2379.

9. Zhong N, Wu XP, Xu ZR, Wang AH, Luo XH, Cao XZ, et al. Relationship of serum leptin with age, body weight, body mass index, and bone mineral density in healthy mainland Chinese women. Clin Chim Acta 2005; 351(1-2):161-168.

10. Obata Y, Yamada Y, Takahi Y, Baden MY, Saisho K, Tamba S, et al. Relationship between serum adiponectin levels and age in healthy subjects and patients with type 2 diabetes. Clin Endocrinol (Oxf) 2013; 79(2):204-210.

11. Ramanand SJ, Ramanand JB, Ghongane BB, Patwardhan MH, Patwardhan VM, Ghanghas R, et al. Correlation between serum adiponectin and clinical characteristics, biochemical parameters in Indian women with polycystic ovary syndrome. IJEC 2014; 18(2):221-225.

\footnotetext{
Authors Contribution:

Dr. Narsingh Verma - Contributed to the original idea, designed the study; Dr. Sunita Tiwari-Conceived hypothesis, designed study, preparing of manuscript and reviewing the manuscript; Dr. Neena Srivastava - Contributed to the study design, data analysis. Dr. Shivani Pandey - Contributed to patient enrolment and biochemical analysis; Dr. Pravesh kumar, Dr. Naveen Bhartia Porwal and Dr. Pradeep Kumar - Contributed to patient enrolment, data analysis, preparing of manuscript and reviewing the manuscript. Dr. Rahul - Contributed to patient enrolment, data analysis, patient blood collection.
}

Source of Support: Nil, Conflict of Interest: None declared. 